\title{
Exploration of Organizational Productivity in Developing Countries
}

\author{
${ }^{1}$ Muhammad Nouman Shafique, ${ }^{2}$ Naveed Ahmad, \\ ${ }^{3}$ Muhammad Shahid Asghar \\ ${ }^{1}$ Ph.D Scholar Preston University, Islamabad \\ ${ }^{2}$ Department of Business Administration, Lahore Leads University, Pakistan \\ ${ }^{3}$ Department of Electronics and Communication, University of Engineering and Technology \\ E-mail address: shafique.nouman@gmail.com, naveeddgk2010@gmail.com
}

Keywords: Organizational Justice; Job Security; Job Satisfaction; Organizational Productivity

\begin{abstract}
Today, Human Resource have identified that competent and skillful employees are the valuable factor in growing and developing organizations. So, respecting their needs their needs management can lead employee job satisfaction. People are the most important in the hospitality organizations because they are the central to the hospitality and service; employees' attitude, behaviors play a significant role to produce quality of services. Customer satisfaction and customers' perception about the quality of services are significantly influenced by the attitudes and behaviors of employees to provide services.

The most industries are creating comparative understandings to keep employees productive and committed at work. Job satisfaction includes evaluative and expectancy components. The job satisfaction as a pleasurable emotional state resulting from the appraisal of one's job or job experience. Job satisfaction as affective response resulting from the evaluation of the work environment to enhance organizational productivity.

Employees' work performance is the degree to which employees are carrying out their jobs in a given tasks. This study contributes to better understanding of fairness perceptions by employees. There is large amount of research in this field, the organization focuses on to attain the expected performance from employees, because employees perform key role to achieve organizational goals.
\end{abstract}

\section{INTRODUCTION}

It has been observed that if organizational decisions are unfair or unjust the affected employees experience feelings of anger, resentment and outrage (Floger, 1987, 1993; Greenberg, 1990b; Sheppard, Lewicki \& Minton, 1992; Skarlicki \&Floger, 1997). In last 25 years the research on organizational justice has been flourished; the main focus has been to investigate the direct effects of organizational justice on employee performance. In the recent years the attention has been paid to the issue of organizational justice and its impacts on organizational productivity.

Organizational justice focuses on employees' perception of fairness which is considered one of the core values covet the organization (Reithel, et al., 2007).The most common policies that used to protect employees against market risk are Employment Protection Legislation (EPL) and Unemployment Insurance Benefits (UIB). Grater the job security is considering discouraging the both practices of Human Resource Management (HRM) hiring and firing. The security is such that an employee with the job would have a small chance of becoming unemployed.

There are some factors that affect job security are economy, prevailing business conditions and the individual personal skills, Human Resource is the most important asset of any organization. Today, Human Resource researchers have identified that competent and skillful employees are the valuable factor in growing and developing organizations. So, respecting their needs management can lead to employee job satisfaction (Part, 1999). The organizational employees should be satisfied, creative, energetic and committed (Shagholi, 1999). 
Employees' negative or positive feeling depends upon job satisfaction (Woo et al., 2005). There are lot of factors that impact on employees' commitment and satisfaction (Thomas et al., 2006). Job satisfaction is overall attitude of his/her (Robins, 1999). According to Smith, Kandall, and Hullin, five traits are remarkable to the job characteristics including job satisfaction, satisfaction from supervisor, satisfaction from colleagues, satisfaction from wage/salary and satisfaction from promotion.

Employees have great impact on organizational productivity. If the attitude is positive and satisfied with their job then organization will perform at stratagem level. Organizational justice and employees' satisfaction has key importance to motivate employees to enhance organizational productivity. The global competition is compelling force behind the organizations to improve their productivity to sustain in competitive market. Employees are the vital force of every organization to improve its productivity. Job security, organizational commitment and job performance are negatively correlated with each other (Rosenblatt and Ruvio, 1996).

The job insecurity reduces job satisfaction and organizational commitment (preuss and Lautseh, 2005). There is significance positive relationship between organizational justice and various areas of organizational commitment (Clay et al., 2005). The purpose of this research is to investigate the impacts of organizational justice, job security and employee job satisfaction on organizational productivity. Therefore the rationale of the study is to analyze the impact of organizational justice, job security and employee job satisfaction, how they are responding to organizational productivity.

\section{RESEARCH QUESTION}

(1) What is the impact of organizational justice on organizational productivity?

(2) What is the impact of job security on organizational productivity?

(3) What is the impact of employee job satisfaction on organizational productivity?

(4) What is the impact of organizational justice on employee job satisfaction?

(5) What is the impact of job security on employee job satisfaction?

\section{LITERATURE REVIEW}

Organizational justice refers to the ethical treatment within an organization (Cropan, 1993). The organizational psychologist refers to the just and fair manner in which organization treat their employees (Greenberg, 1990b). The focus of research shifted to the procedural justice, perceived the fairness in which outcomes were determined (Cropanzan\&Randall, 1993), dueto inability of equity theory and distributive justice models (Crosby, 1976; Deutsch, 1975; Floger, 1984).

To fully predict and explain peoples' reactions to perceived injustice. The distinction between distributive and procedural justice has been supported by research (Alexander \&Ruderman,1987 ; Floger \& Konovsky , 1989; Gilliland , 1994; Sweeney \& McFarlin ,1993).According to Dye (1990), number on rule for human resource practioners in the principals of fairness. It has been observed that if the organizational decisions are unfair or unjust the affected employees experience of outrage, resentment and anger (Folger, 1987, 1993; Greenberg, 1990b; Sheppard, Lewicki \& Minton, 1992; Skarlicki \& Floger, 1997).

In last 25 years the research on organizational justice has been flourished; the main focus has been to investigate the effects of organizational justice on employee performance. The organizational justice has been attracting attention to investigate its impact on organizational performance. The organizational justice focuses on employees' perception of fairness which is considered one of the core values covet the organization (Reith, et al., 2007). The importance of organizational justice is being explored by researchers (Ambrose, 2002).

Individuals in organizations expected to compare their input to output ratio to perceive the level of organizational fairness. The organizational justice was influenced by focus of distributive justice (Reith et al., 2007).Researchers beliefs that potentials benefits of meta-analysis on organizational justice (Corpanzano et al., 2001). The Meta -analysis explain the power of 
moderator variable likely to be strong (Cohen-Charash\& Spector, 2001). The organizational justice was influenced by conducting study collectively on distributive and procedural justice.

The researchers began to investigate the aspects of organizational justice related to interpersonal treatment of employees and conceptualization of interactional justice (Bies\& Moag,1986). The interactional justice viewed as two types of interpersonal treatments (Greenberg , 1990a , 1993b). The first interpersonal justice reflects the degree to which people treated with dignity, politeness and respect by authorities involved in determining outcomes. The second is informational justice, focus on explanations \& information provided to people that argue about why procedures were used in a certain way or why outcomes were distributed in a certain fashion (Colquitt et al., 2001).

The research supports the distinction between distributive and procedural justice (Alexander \& Ruedrman, 1987: Floger \& Konovsky, 1989; Gilliland, 1994; Sweeny \& McFarlin, 1993). Whereas less agreement is found in difference between procedural justice and interactional justice. While some researchers have supported the distinction (Colquitt, 1991; Corpanzano \& Preher , 1999 ; Moorman , 1991) while some researchers have questioned the relationship ( Byrne \&Corpanzano, 1999; Tyler \& Bies, 1990).

Distributive, procedural and interactional justices are strongly correlated (Cohen- Charash et al., 2001). Justice or fairness perceptions are not only -correlated with attitudes and behaviors ; there is also a casual evidence of positive effects of fairness, when after managers have been trained to be fair, employees demonstrate increase extra- role behaviors ( Skarlicki\&Latham 1996,1997) and decrease the employees' stress level ( Greenberg , 2006). The dictionary define the word justice as fairness (popular oxford New - age primary school Dictionary).

However the justice term used in daily life as otherness or rightness. In social psychological research, attitudinal. Fairness, an event, action or decision is judged as fair or unfair based upon the individual beliefs (Bies, 1987). The fairness of perception is divided into two types (1) Outcome distributions and allocations (2) procedures to determine outcome distributions and allocations. These forms of justice are typically referred to as distributive justice (Adams , 1965; Deutsch , 1975; Homans , 1961; Leventhal , 1976) and procedural justice ( Leventhal , 1980; Leventhal , Karuza\& Fry, 1980; Thibaut\& Walker, 1975).

Respectively, the distributive justice refers to "the fairness of outcome distributions and allocations" (Adams, 1965; Deutsch, 1975; Homans, 1961; Leventhal , 1976). Procedural justice refers to "the fairness of the procedures used to determine outcome distributions or allocations" (Leventhal, 1980; Leventhal et al., 1980; Thibaut\&Walker, 1975). However third type of justice called interactional justice and associated with human side of organizational practices, these three types are correlated (Erdogan, 2002).

Employee's positive attachment to the organization is considered employee's affective commitment. An employee who is affectively committed to the organization strongly identifies the goals of organization and desire to remain the part of the organization. Meyer and Allen (1991) drew largely on the conceptualization of commitment. Adnan and Muhammad (2010) if the employees are promoted on the basis of performance, then it increases job satisfaction and in the same study the job commitment was found positively correlated to the job satisfaction.

Mosadeghrad et al., (2008) investigated the relationship between job satisfaction, organizational commitment and turnover intention among hospital employees. The study conducted by Lew (2008) on job satisfaction and effective commitment of employees in tourism. Three most important factors opportunities for advance development, job security and interesting work. The study concluded that job satisfied employees are more committed to offer high quality service to the customers. The target performance needs to be seen as achievable and worthwhile.

Beyond the setting of objective, there is problem of attaching rewards to achieve these objectives. Rewards are one of the way in which organization structure build relationship with their employees and relationship to emphasize performance (Kessler and Purcell, 1992; Procter, McArdle, Rowlinson, Forrester and Hassard, 1993; Gibson, 1995). The performance Management system attaches rewards to performance; it put impact on entire relationship of employer and 
employee. It effect on the culture of the organization and its sub-cultures (Bento and Ferreira, 1992).

The agency theory as a theoretical framework is characterizing the compensation process in businesses (Gomez-Mejia, Larraza, Makri, 2003). The agency theory has greatly increased understandings towards executive compensation at the lower level of the firms. Somewhat is known about the employee compensation determinants from the perspective of agency theory ( Werner , Tosi , \& Gomez - Mejia, 2005). The reasonable balance between employee commitment and organization's performance is the most requirement of the organizations in this global competition.

Entwistle (19870 argue that the successful performance of an employee's leads to organizational rewards as a result motivational factor of employees which compelled to perform. The research conducted to investigate the relationship between individual's focus and compensation was to enhance the performance of employees (Cisel, 1974). The motivated employees considered as a competitive force to improve to improve the organizational performance. According to Andrew (2004) employee's commitment depends upon rewards and recognition.

Lawler (2003) argued that survival \& prosperity of the organization determine through how human resource is treated. The work related behavior of employees in organizational affective commitment has been identified as a critical factor. Mowday, Strees, and Porter (1979) discussed affective commitment in two perspectives: attitudinal and behavioral. An attitudinal perspective defines organizational affective commitment in form of attachment to an organization, affective responses and cognition. Behavioral approaches discuss and focus on the behaviors of employees related to an organization.

Becker (1960) used the term side-bet to clarify the affective commitment. Side-bet refers to the accumulation of investments valued by individuals that would be lost if the employees were leave the organization. In other words, Becker argued that affective commitment is consistent lines of activity, tendency to engage, maintaining membership in organization. These lines of activities involve staying with the organization, turnover cost, including the loss of turnover, disruption of relationship with an organization and effort of seeking a new job. Thus, the behavioral perspective focuses on the over manifestations of affective commitment (Mowday et al., 1979).

Sheldon (1971) argued that attitudinal commitment is identification of linked a person with an organization. Hall, Schneider, and Nygren (1970) argued that organizational goals and individual's goals become integrated and attitudinal commitment represents the state of individual's and organizational goals and maintain relationship to facilitate goals (Modway et al., 1979). Most definitions of organizational affective commitment explains the terms of extent to which employees identify and correlate with an organization (Curry, Wakefield, Price , \& Mueller , 1986) for example, Steer (1977) argued that organizational affective commitment is a relative strength of an employee with an involvement in a particular organization.

Modway et al., (1979) defined a passive loyalty to an organization is organizational affective commitment. PorterSteers, Mowday, and Boulian (1974) identified three related factors of organizational affective commitment. Beliefs on organizational goals \&values, desire to maintain strong membership with an organization and willingness to exert considerable effort for an organization. The organizational affective commitment differs from the concept of employee job satisfaction. Organizational affective commitment focuses on attachment to employing organization, while job satisfaction emphasizes the specific task environment where an employee performs his/her tasks.

The organizational affective commitment appears to develop slowly but consistently as employee think about their relationship with an organization. This type of affective commitment is less affected by day-to-day events in the workplace (Mowday et al., 1979). De Cotiis and summers (1987) argued that organizational affective is two dimensional. The $1^{\text {st }}$ dimension is the organizational goal and value internalization and $2^{\text {nd }}$ dimension is in terms of goals and values. Human resource plays a vital role in any organization to accomplish its goals.

Deeprose (1994) commented that employee's motivation and productivity can improve by providing them recognition which ultimately results to improve organization's productivity. 
Freedman (1978) argued that effective rewards create favorable environment to motivate employees within organization. Flynn (1998) rewards keeps high spirits among employees improve their morale and create linkage between performance and employees' motivation to achieved assigned goals. Bull (2005) when achieve target, they experience their skills and abilities and experienced greater level of job satisfaction, rewards, incentives are key factors that motivate employees to perform in an organization.

The study of employee compensation and reward has major practical implications. Employee compensation and reward cost often exceed $80 \%$ of total operating expenses (Gomez-Mejia and Balkin, 2006). The analysis has even greater interest where lower levels of management hierarchy exist (Galve\& Salas, 2003; Van Steel \&Stunnenberg, 2006). Compensation costs at operational level are consequently even higher. A few studies have dealt with employee compensation contracts (Werner et al., 2005).

Significance differences in compensation practices apply to all employees' functions in the organization. Profit sharing plans align the objectives of employees with firm (Rayton , 2003).Few studies relate that employee pay levels to the ownership structure of the organization from focus on executives (Core, Holthausen, \& Lareker, 1999; Ramasuwamy, Veliyath \& Gomes , 2000), show that if managers pay level decreases as the CEO's level of ownership increases. In nonfamily CEO is not an owner and the ownership concentration which will influence the decision of CEO's directed towards personal gain, higher salary and status within the firm (Baumol, 1959).

The firms has been used the stock based compensation and reward to the top management and key employees of the organization. Now many companies consider employees are key for organization's success. In April 2002, the national center for employees' ownership estimates that 8.8 million employees participated in Equity Based Compensation Plans (EBCPs). Researchers have investigated incentives and mechanisms of different compensation policies and procedures; the focus was on pay performance and compensation packages (Gibbons and Waldman, 1999; Murphy, 1999).

The majority of the published literature existed focuses on developed countries due to maturity of labor market as compare to developing countries. Chinese enterprises given the significant role in economy (Naughton, 1995; Yang, 1997; Megginson and Netter, 2001). Several studies showed the impact of reform on productivity of Chines state-owned enterprises (SOEs) the performance improved after reforms (Chen et al., 1988; Dollar, 1990; Woo et al., 1994). The implementations of Government's incentives and compensation plan for executives and managers found more effective because they sold the main principal- agent problems (McNeil, 2004).

The previous research shows that the most effective way to solve the principal-agent problem is to determine executives payments based on firm's long-term performance which makes the deferred compensation policy necessary (Coughlan and Schmidt, 1985; Murphy, 1986; Abowd ,1990; Jenson and Murphy , 1990; Leonard, 1990). Wallach (2003) the published literature on deferred compensation highlights the benefits of deferred compensation for executives, employees and in aspects of wealth accumulation, control \& cost.

A few analyze compensation policies and procedures in China, find managers pay related to firm's performance. Managers have been fired out as a result of poor performance since the industrial reforms of 1980 (Groves et al., 1995). Lincoln and Kalleberg (1990) have argued that organizational rewards put powerful effect on employee's attitude towards their job and the organization where they do work. It is important to highlight the difference between intrinsic and extrinsic rewards. Intrinsic rewards are those that exist in the job itself and extrinsic rewards on the other hand comprise elements pay and the fringe benefits, advance opportunities and promotion within the organization.

Caldwellet al., 1990; O' Reilly \& Chatman (1986) argued that intrinsic rewards more effective for commitment whereas extrinsic rewards are important in relation to continuance commitment. Compensation enhances the employee's satisfaction and performance in any organization (Porter and Lawler, 1986). There are two broad types of intrinsic and extrinsic 
rewards, typically extrinsic rewards is the monetary compensation and intrinsic include personality satisfying, personal growth, feelings of achievement and social status (Hellriegel et al., 1999).

Taiwanese firm employee's rewards consist on three components, Basic salary, a year end bonuses and employees' bonus. One problem with the specification that replaces expected future abnormal earnings by current earnings that the future growth will be prosper potently important correlated omitted variable (Skinner, 1996). Organizations in today's environment seek balance between organizational performance and employee commitment. The rewards are the most contingent factor to keep employees' self-esteem high and passionate towards their job.

Oosthuizen (2001) argued that it is the function of managers to motivate employees and influence their behavior to enhance the organizational productivity and efficiency. La Motta (1995) the job performance is the result of ability and motivation. Entwistle (1987) argued that employees perform successfully, it leads to organization as a result motivational factor of employees. The investigations shows that the relationship between employees, compensation and individual were focused to increase the performance of employees (Ciscel, 1974).

Organizations usually reward and compensate to enhance the motivational level of employees' and to improve organizational productivity. All those things that employees get in return of their efforts and work that they contribute for achieving organizational goals considered rewards and compensation. Fry (2004) found that there is positive relationship between equity based compensation and employee performance. It was concluded that compensation play vital role in human intensive firms to retain and attract competitive workforce.

Nevertheless, the compensation put significant impact on job satisfaction of employees. Factors like job insecurity, nature of work, working conditions, low wages and lack of promotion have adverse effect on level of job satisfaction of employees ( Silla et al ., 2005). Contractual employees are less loyal then permanent employees because they have not been attain many permanent facilities job security, perks these factors have direct correlation with employees performance ( Anwar S.M et al ., 2011).

The organizational justice and employee satisfaction play important role to improve organizational productivity. The research was conducted on job security and it was found that organizational commitment and job performance are negatively correlated with job security (Rosenblatt and Ruvio, 1996). Every employee has different skills and capabilities which cannot be matched with another. There is different relationship between employee performance and job security. The organizational employees should be satisfied, creative, energetic and committed (Shagholi, 1999).

Today, Human Resource researchers have identified that competent and skillful employees are the valuable factor in growing and developing organizations. So, respecting their needs their needs management can lead employee job satisfaction (Part, 1999). People are the most important in the hospitality organizations because they are the central to the hospitality and service; employees' attitude, behaviors play a significant role to produce quality of services. Customer satisfaction and customers' perception about the quality of services are significantly influenced by the attitudes and behaviors of employees to provide services (Bitner , Booms , \&Tetreault , 1990; Parasurman, Zeithmal, \& Berry, 1988 ; Schneider \& Bowen , 1993 ).

The interaction among employees and customers is essential in a service delivery to the satisfaction and dissatisfaction of customers (Bitner, Booms, \&Tetreaul, 1990). Employees are the responsible for providing competitive advantage for service industry. Nevertheless, the success of services industry depends on the retention of employees (Wood, 1992).Job satisfaction is one the most widely studied in management literature and organizational behavior. The job satisfaction proceeds from its relationships to others accept of organizational results, organizational performance and employees' turnover.

The most industries are creating comparative understandings to keep employees productive and committed at work and thus call for the study of job satisfaction and related factors (Smith, 1992). The theoretical definition of job satisfaction includes evaluative and expectancy components. Locke (1976) argued that the job satisfaction as a pleasurable emotional state resulting from the 
appraisal of one's job or job experience. Similarly, Mottaz (1988) regarded job satisfaction as affective response resulting from the evaluation of the work environment.

The job satisfaction is a function of work-related rewards and values related to the job performance (Vroom, 1964; Kaleberg, 1977). The job redesign means enhancing job satisfaction and making job more interested (Herzberg, 1968; Herberg, Mausner, \& Snyderman, 1959). This is due to by changing the characteristics of job and tasks. The job characteristic refers to the content and nature of the job tasks themselves (Spector, 1997). The job characteristics affect the people is the most influential theory of Hackman and Oldham's (1980).

The employees can be motivated by intrinsic satisfaction and they find in doing job tasks. People motivated and satisfied when they find their job meaningful and interested. According to the job characteristics five core characteristics can be applied to any job. Task significance, task identity, skill verity, autonomy and feedback. The five core characteristics are thought lead to the three. Psychological states, which includes, experienced, responsibility for outcomes of the work, meaningfulness experienced of work and knowledge of actual results of the work.

Task significance, task identity and skill verity combine to produce a meaningful work experience. Autonomy leads to feelings of responsibility, feedback results in knowledge of the results of produced products or services. Three psychological states in turn contribute to critical outcome of employee motivation and job satisfaction (Spector, 1997).In, other words these psychological states are present to enhance the employee's motivation, performance and satisfaction. The facet approach can be helpful for the organization to identify the areas of dissatisfaction that they can improve upon (Spector, 1997).

A job satisfaction facet can be related to any aspect of the job, including rewards, supervisors, Coworkers, the work itself and the organizational. Spector (1997) argued that the facet approach can be providing a job satisfaction level of employees, because the employees feel different about coworkers and dislike pay. Job satisfaction is overall attitude of his/her (Robins, 1999). According to smith, kandall and Hullin, five traits are remarkable to the job characteristics including job satisfaction, satisfaction from supervisor, satisfactions from colleagues, satisfaction from wage/ salary and satisfaction from promotion.

Weiss (2002) has argued that the job satisfaction is overall attitude of employees' towards feelings, beliefs and behaviors. The job satisfaction of employee is define the overall certain facts of the job, such as work itself, co-workers, working conditions, company policies , procedures , pay and opportunities for promotion ( Smith et al ., 1969). The study was conducted by Gunlu et al., (2010) in Turkey on job satisfaction and organizational commitment of managers in hotel industry, job satisfaction have a significant effect on normative and effective commitment.

A comparative study conducted by Kwants (2009) in India and America on organizational commitment and job satisfaction. The job satisfaction is found to relate to affective commitment in both the India and American samples. The organizational commitment, turnover intention and job satisfaction among hospital employees. The result indicated that hospital employees are moderately satisfied and committed towards their job and organization.

The organizational commitment, employees' job satisfaction and turnover intention were interrelated. Lew (2008) conducted study on tourism industry and argued that interesting work; opportunities for advancement, development and job satisfaction motivate employees and affective commitment in tourism industry. The employee job satisfaction refers to the degree to which employees feel positively or negatively about their jobs. It is based on assessing the job and job related experience (Locke, 1976).

Employees' work performance in the degree in which employee are carrying jobs in a given work tasks (Suliman, 2007). Low level of job satisfaction among employees has been shown undesirable behaviors such as practical and psychological withdrawal from the job, using organizational time to pursue personal tasks and behavioral changes that impact on workplace environment (Camp, 1994). Additional negatives consequences related to low level employees' job satisfaction include higher rates of turnover and lack of active participation in job related tasks (Camp, 1994). 
The working environment that meets the needs and values of employees and the individual's response to that environment refers to the job satisfaction (Camp, 1994; Lambert, 2004; Tewksbury \& Higgins, 2006). In studies Camp (1994) and Lambert (2004) concluded that job satisfaction was measured from supervision, coworkers, pay and promotion. Human resource is the most vital asset that makes other resources use and gets best return out of them. If the human resource is happy and contented with the moves and actions of employer they do their best for the organization.

Management always tries to implement strategies and plans to satisfy their workforce. The grater the level of satisfaction of workforce and higher will be return for organization. Employees' job satisfaction improve the retention ratio and reduce the cost of hiring new employees (Murray, 1999). Alternatively, job dissatisfaction increases the cost of recruitment, Training \& selection, reduction into growth of organization and discouragement of employees (Padilla - Velez, 1983). J

ob satisfaction is an outcome of different factors like, relationship with co-workers, pay, promotion, supervision, the work itself and the opportunities for promotion (Opkara, 2002). Pay is the most important factor out of these. Frye (2004) argued that there is positive relationship between performance and compensation. It was also investigated that flexible compensation has no effect on the level of employees' job satisfaction (Igalens and Roussel, 1999).

The income is the major determinant of job satisfaction for the managers of public sector (Sokoya, 2000). The job satisfaction is affected by the pay (Nguyan et al., 2003). The job dissatisfaction is the outcome of insecurity among employees (Ashford et al., 1989; Davy et al., 1991). Rosow and Zager (1985) concluded that job insecurity decreases the employee job performance. Iverson (1996) argued that job security put positive impact on organizational commitment.

The job insecurity, job performance and organizational commitment are negatively correlated with job insecurity. Rosenblatt and Ruvio (1996). The job is associated with dimensions like, task identify, task significance, skill Varity, autonomy and feedback (Glisson\&Durick, 1988). Various studies have been conducted to investigate the predictors of employee job satisfaction among police officers and correctional personnel ( Balu , Light \&Chamlin , 1986; Brough\& Frame , 2004; Brunetto\&Farr - Wharton , 2003; Cullen , Latessa , Kopache , Lombardo , \& Burton , 1993; Lambert, 2004; Lambert et al ., 1999; Zhao , \& He, 1999).

Zhao et al ., (1999) indicated that job satisfaction models, the first model focuses on demographic, characteristics such as educational level, rank, ethnicity/race, gender and year of service within the organization. The second model places emphasis on individual's work environment. The work environment consist on different dimensions of work performed, task significance, task identity, skill Varity and feedback (Zhao. 1999). It is depend upon job and jobrelated experience with some degree of favor and disfavor (Lake, 1976).

\section{Conclusion}

The job insecurity, job performance and organizational commitment are negatively correlated with job insecurity. The job is associated with dimensions like, task identify, task significance, skill Varity, autonomy and feedback. Various studies have been conducted to investigate the predictors of employee job satisfaction among police officers and correctional personnel.

Employees' work performance is the degree to which employees are carrying out their jobs in a given tasks. This study contributes to better understanding of fairness perceptions by employees. There is large amount of research in this field, the organization focuses on to attain the expected performance from employees, because employees perform key role to achieve organizational goals.

\section{HYPOTHESIS FOR FUTURE RESEARCH}

The organizational justice and job security is positively associated with employee job satisfaction and organizational productivity.

$\mathrm{H} 1$; Organizational justice is positively associated to organizational productivity.

$\mathrm{H} 2$; Employee job security is positively associated to organizational productivity.

H3; Employee job satisfaction is positively associated to organizational productivity. 
$\mathrm{H} 4$; organizational justice is positively associated to employee job satisfaction. H5; Job security is positively associated to employee job satisfaction.

\section{References}

[1] Aryee, S., Budhwar, P. S., \& Chen, Z. X. (2002). Trust as a mediator of the relationship between organizational justice and work outcomes: Test of a social exchange model. Journal of Organizational Behavior, 23(3), 267-285.

[2] Bateman, T. S., \& Organ, D. W. (1983). Job satisfaction and the good soldier: The relationship between affect and employee "citizenship". Academy of management Journal, 26(4), 587-595.

[3] Bertola, G. (1990). Job security, employment and wages. European Economic Review, 34(4), 851-879.

[4] Brayfield, A. H., \& Rothe, H. F. (1951). An index of job satisfaction. Journal of applied Psychology, 35(5).

[5] Clark, A., \& Postel-Vinay, F. (2009). Job security and job protection. Oxford Economic Papers, 61(2), 207-239.

[6] Colquitt, J. A. (2001). On the dimensionality of organizational justice: a construct validation of a measure. Journal of applied Psychology, 86(3).

[7] Colquitt, J. A., Conlon, D. E., Wesson, M. J., Porter, C. O. L. H., \& Ng, K. Y. (2001). Justice at the millennium: a meta-analytic review of 25 years of organizational justice research. Journal of applied Psychology, 86(3).

[8] Cropanzano, R., Byrne, Z. S., Bobocel, D. R., \& Rupp, D. E. (2001). Moral virtues, fairness heuristics, social entities, and other denizens of organizational justice. Journal of Vocational Behavior, 58(2), 164-209.

[9] Cropanzano, R., \& Greenberg, J. (1997). Progress in organizational justice: Tunneling through the maze. International review of industrial and organizational psychology, 12, 317372 .

[10] Davy, J. A., Kinicki, A. J., \& Scheck, C. L. (1997). A test of job security's direct and mediated effects on withdrawal cognitions. Journal of Organizational Behavior, 18(4), 323349.

[11] Fallon, P. R., \& Lucas, R. E. B. (1993). Job security regulations and the dynamic demand for industrial labor in India and Zimbabwe. Journal of development Economics, 40(2), 241-275.

[12] Ferrie, J. E., Shipley, M. J., Stansfeld, S. A., \& Marmot, M. G. (2002). Effects of chronic job insecurity and change in job security on self reported health, minor psychiatric morbidity, physiological measures, and health related behaviours in British civil servants: the Whitehall II study. Journal of epidemiology and community health, 56(6), 450-454.

[13] Folger, R. G., \& Cropanzano, R. (1998). Organizational justice and human resource management (Vol. 7): sage publications.

[14] Fox, S., Spector, P. E., \& Miles, D. (2001). Counterproductive work behavior (CWB) in response to job stressors and organizational justice: Some mediator and moderator tests for autonomy and emotions. Journal of Vocational Behavior, 59(3), 291-309.

[15] Greenberg, J. (1987). A taxonomy of organizational justice theories. Academy of Management review, 12(1), 9-22.

[16] Greenberg, J. (1990). Organizational justice: Yesterday, today, and tomorrow. Journal of management, 16(2), 399-432. 
[17] Gregg, P., \& Wadsworth, J. (1995). A short history of labour turnover, job tenure, and job security, 1975-93. Oxford review of economic policy, 73-90.

[18] Harris, D. H., \& others. (1994). Organizational Linkages:: Understanding the Productivity Paradox: National Academies Press.

[19] Heckman, J. J., \& others. (2000). The cost of job security regulation: evidence from Latin American labor markets: National bureau of economic research.

[20] Hoppock, R. (1935). Job satisfaction.

[21] Jackson, T. W., Dawson, R., \& Wilson, D. (2003). Understanding email interaction increases organizational productivity. Communications of the ACM, 46(8), 80-84.

[22] Judge, T. A., Locke, E. A., \& Durham, C. C. (1997). The dispositional causes of job satisfaction: A core evaluations approach. RESEARCH IN ORGANIZATIONAL BEHAVIOR, VOL 19, 1997, 19, 151-188.

[23] Judge, T. A., Thoresen, C. J., Bono, J. E., \& Patton, G. K. (2001). The job satisfaction-job performance relationship: A qualitative and quantitative review. Psychological bulletin, $127(3)$.

[24] Lazear, E. P. (1990). Job security provisions and employment. The Quarterly Journal of Economics, 699-726.

[25] Locke, E. A. (1969). What is job satisfaction? Organizational behavior and human performance, 4(4), 309-336.

[26] Locke, E. A. (1976). The nature and causes of job satisfaction. Handbook of industrial and organizational psychology, 1, 1297-1343.

[27] Masi, R. J., \& Cooke, R. A. (2000). Effects of transformational leadership on subordinate motivation, empowering norms, and organizational productivity. The International Journal of Organizational Analysis, 8(1), 16-47.

[28] Mobley, W. H. (1977). Intermediate linkages in the relationship between job satisfaction and employee turnover. Journal of applied Psychology, 62(2).

[29] Moorman, R. H. (1991). Relationship between organizational justice and organizational citizenship behaviors: Do fairness perceptions influence employee citizenship? Journal of applied Psychology, 76(6).

[30] Park, K.-O., Wilson, M. G., \& Lee, M. S. (2004). Effects of social support at work on depression and organizational productivity. American Journal of Health Behavior, 28(5), 444455 .

[31] Porter, L. W., Steers, R. M., Mowday, R. T., \& Boulian, P. V. (1974). Organizational commitment, job satisfaction, and turnover among psychiatric technicians. Journal of applied Psychology, 59(5).

[32] Pritchard, R. D. (1990). Measuring and improving organizational productivity: A practical guide: Greenwood Publishing Group.

[33] Pritchard, R. D. (1992). Organizational productivity. Handbook of industrial and organizational psychology, 3, 443-471.

[34] Pritchard, R. D. (1995). Productivity measurement and improvement: Organizational case studies: Greenwood Publishing Group.

[35] Pritchard, R. D., Jones, S. D., Roth, P. L., Stuebing, K. K., \& Ekeberg, S. E. (1988). Effects of group feedback, goal setting, and incentives on organizational productivity. Journal of applied Psychology, 73(2). 
[36] Rodgers, R., \& Hunter, J. E. (1991). Impact of management by objectives on organizational productivity. Journal of applied Psychology, 76(2).

[37] Sverke, M., Hellgren, J., \& Näswall, K. (2002). No security: a meta-analysis and review of job insecurity and its consequences. Journal of occupational health psychology, 7(3).

[38] Tjosvold, D. (1988). Working together to get things done: Managing for organizational productivity: Free Press.

[39] Williams, L. J., \& Anderson, S. E. (1991). Job satisfaction and organizational commitment as predictors of organizational citizenship and in-role behaviors. Journal of management, 17(3), 601-617.

[40] Yousef, D. A. (1998). Satisfaction with job security as a predictor of organizational commitment and job performance in a multicultural environment. International Journal of Manpower, 19(3), 184-194. 